\title{
PUBLIC NARRATION AND MUSLIM COMMUNITY PARTICIPATION TOWARD THE LIVING ENVIRONMENT MANAGEMENT IN BUKITTINGGI
}

\author{
Januar \\ Institut Agama Islam Negeri (LAIN) Bukittinggi \\ e-mail:eljanuar78@gmail.com
}

Eka Rizal

Institut Agama Islam Negeri (LAIN) Bukittinggi

e-mail:eka_rizal@gmail.com

\begin{abstract}
The increasing and spreading of the population in Bukittinggi emerge several environmental problems, such as; the population density above 500 people per hectare, air pollution, traffic congestion, limited sources of clean water, limited green space for the people, poor sanitation, and drainage, and the poor of city planning and construction. One of the crucial issues of environmental management is the low participation and awareness of the community on waste management even they are the strong adheres of religious beliefs and culture. How the public narration and opinion on the awareness of preserving the environment so that it affects the participation of the Muslim communities on environmental management is a phenomenon that will be answered in this study. This qualitative study has found that the narration of Muslim community awareness does not affect their participation in environmental management, especially community-based waste in Bukittinggi City, which in general has not been going correctly. There are other factors outside of the religious awareness and cultural factors in the lack of community participation, such as, the implementation of regulations and environmental policies and the absence of precise planning in the management of community-based solid waste management because of several obstacles including the lack of community awareness, the absence of waste management and limited funding processing.
\end{abstract}

Keywords: Religion narration, Community participation, Waste and the environment

\section{Abstrak}

Pertambahan jumlah dan penyebaran penduduk di Kota Bukittinggi menimbulkan persoalan lingkungan seperti; kepadatan jumlah penduduk di atas 500 jiwa per hektar, polusi udara, kemacetan lalu lintas, terbatasnya sumber air bersib/minum, terbatasnya ruang terbuka bijau bagi warga, buruknya sanitasi dan drainase, serta jeleknya penataan kota dan pembangunan. Salab satu persoalan krusial dalam pengelolaan lingkungan seperti persoalan sampab adalah rendahnya partisipasi dan kesadaran masyarakat yang notabenenya kuat menganut keyakinan agama dan kultur budaya. Bagaimana narasi dan opini masyarakat terhadap kesadaran menjaga lingkungan sehingga mempengarubi partisipasi masyarakat Muslim dalam pengelolaan lingkungan bidup merupakan fenomena yang akan dijawab dalam penelitian ini. Penelitian Kualitatif ini telah menemukan bahwa narasi tentang kesadaran masyarakat Muslim tidak mempengarubi partisipasi mereka dalam pengelolaan lingkungan terutama sampah berbasis masyarakat di Kota Bukittinggi yang secara umum belum berjalan dengan baik. Ada faktor lain diluar faktor kesadaran beragama dan kultur budaya dalam rendabny a partisipasi masyarakat seperti belum terlaksananya peraturan dan kebijakan lingkungan, babkan ditambah belum adanya perencanaan khusus dalam management pengelolaan sampah berbasis masyarakat karena beberapa kendala diantaranya minimnya kesadaran masyarakat, tidak adanya tempat pengelolaan sampah dan keterbatasan biaya pengolahan.

Kata Kunci: Narasi agama, Partisipasi masyarakat, Sampah dan lingkungan

\section{Background}

An environment is a part of human life integrity. So, the environment must be seen as one component of the ecosystem that has value to be respected, valued, and preserved. The environment has a value to itself. This integrity causes every human behaviour can affect the surrounding environment. Positive 
behaviour can preserve the sustainable environment and negative behaviour can damage the environment integrity. This integrity also causes humans to have the responsibility to behave well with the life around them. The destruction of nature is caused by the anthropocentric human perspective which seeing the humans as the centre of the universe.

The unbalance population increasing and spreading could cause the environmental problems, such as; population density above 500 people per hectare, air pollution, traffic congestion, limited sources of clean water, limited green space for the people, poor sanitation and drainage, and poor city planning and development ${ }^{1}$. In the past of four decades, scientists have noted a variety of environmental damage such as the increasing of air pollution, rivers and oceans. In addition, this environmental damage reduces and decrease the groundwater level ${ }^{2}$. These environmental problems have a negative impact on humans, such as flood, landslide, limited to a water source, garbage, and poor drainage.

For the local context of Bukittinggi City, waste management is an important point in the current environmental problems. With a dense population of 121,845 people, waste management is a serious problem for the Bukittinggi City Government, especially in terms of waste management and processing. Previously, the waste in Bukittinggi City conducted open dumping at the Panorama Baru Final Processing Site (TPA), which was considered to be in violation of the rules and had to be closed immediately, because it could not be used in the long term. ${ }^{3}$ After the

${ }^{1}$ Sarlito Wirawan Sarwono, Psikologi Lingkungan (Jakarta: PT Gramedia, 1992), p. 122.

2 Johan Iskandar, Ekologi Manusia dan Pembangunan berkelanjutan, (Bandung: Program Studi Magister Ilmu Lingkungan Universitas Padjajaran, 2009), p. 6.

${ }^{3}$ Putri Nilam Sari, 'Analisis Pengelolaan Sampah Padat Di Kecamatan Banuhampu Kabupaten Agam', issuance of Law 18 of 2008 concerning Waste Management Article 29 paragraph 1, there is a prohibition on handling waste disposal in an open space. Furthermore, the government carries out the waste disposal at the Regional Final Processing Site (TPA) of Payakumbuh based on the Memorandum which is approved by the Government Provinces as Facilitators and five districts/cities that participated in the agreement ${ }^{4}$.

Based on the above phenomenon, it can be analyzed that there is still a lack of participation of urban communities on environmental issues. In fact, according to the government, the societies still go littering in drainages and irregular sanitation disposal. Meanwhile, the communities assume that the cause of these environmental problems is the lack of facilities and uncontrolled development supervision. The construction of roads and buildings neglect the use of drainage and good environmental governance. Various reasons, narrations, and opinions develop in this environmental issue. Even though the societies are strong Islamic adherents and culture.

Thus, it is interesting to actually examine the narration and participation of Muslim communities in the environment. The research on the Muslim community participation in environmental issues and crises is rarely found. Only a few studies such as Herawati ${ }^{5}$ and Sulistiyorini's research ${ }^{6}$ focused on community

Jurnal Kesehatan Masyarakat Andalas, 10.2 (2017), 157 <https://doi.org/10.24893/jkma.v10i2.201>.

4 Sri Dzarrah Hayati Manvi, 'Efektifitas Pelaksanaan Pembuangan Sampah Kota Bukittinggi Ke Tempat Pemrosesan Akhir (TPA) Regional Kota Payakumbuh Menurut Undang-Undang No 18 Tahun 2008 Tentang Pengelolaan Sampah' \{unpublished bachelor thesis, UMSB Sumatera Barat, Padang, 2004\}, p. 12.

${ }^{5}$ Devi Hernawati, Choirul Saleh, and Suwondo, 'Partisipasi Masyarakat dalam Pengelolaan Sampah Berbasis 3R (Reduce, Reuse dan Recycle) (Studi Pada Tempat Pengelolaan Sampah Terpadu di Desa Mulyoagung Kecamatan Dau Kabupaten Malang)', Jurnal Administrasi Publik (JAP), 1.2 (2019), 181-87 <https://doi.org/10.1017/CBO9781107415324.004>.

${ }^{6}$ Nur Rahmawati Sulistiyori Sulistiyorini, Rudi Saprudin Darwis, and Arie Surya Gutama, 'Partisipasi 
participation in waste management, while Nabila was more focused on the community empowerment model on environmental management.

The research on the participation of Muslim communities on the environment is very interesting to examine especially related to their narration and participation with changes in community culture from rural culture to urban culture in the midst of information flow and globalization. Thus, this study focused research on how public narration and Muslim community participation on the environmental phenomena and policies in Bukittinggi.

\section{Public Participation in Theoretical Framework}

Participation is a basic right of the public. Therefore, participation is not an obligation of the community. Participation is an activity carried out to demand the fulfilment of public basic rights. The fulfilment of these basic rights is carried out by the state through public service policies. The public is the subject who realize their rights. Therefore the public is the sovereign in determining public service policies ${ }^{7}$.

Simply, the meaning of participation is one's participation in an activity. Moeliono gives a brief definition of participation which means to participate in an activity ${ }^{8}$. In Soetomo's development discourse, there are six different interpretations and meanings about participation. First, participation is the voluntary contribution of the community to the project without participating in decision making. Second; participation is an effort to make the community more sensitive in increasing willingness to accept and the ability

Masyarakat dalam Pengelolaan Sampah di Lingkungan Margaluyu Kelurahan Cicurug', Prosiding Penelitian dan Pengabdian Kepada Masyarakat, 3.3 (2016), 414 <https://doi.org/10.24198/ippm.v3i3.13786>.

${ }^{7} \mathrm{~N}$ Saribanon and others, 'Pendekatan Tipologi dalam Pengembangan Partisipasi Masyarakat', Jurnal Pengabdian Masyarakat, 8.3 (2007), 235-44.

${ }^{8}$ Moeliono, A.M., Kamus Besar Bahasa Indonesia (Jakarta: Balai Pustaka, 1990), p. 978. to respond to development projects. Third; participation is an active process that contains the meaning that the person or group concerned takes the initiative and uses their freedom to use it. Fourth; participation is strengthening dialogue between local communities and staff in carrying out project preparation, implementation and monitoring in order to obtain information about the local context and social impacts. Fifth; participation is voluntary involvement by the community in self-determined changes. Sixth; participation is community involvement in the development of themselves, their lives and their environment?

According to Thoha in Nur Jihad classifies community participation into three groups, namely independent participation which is an effort to participate that is carried out independently by the culprit, mobilization participation, and ceremonial participation. In order that the community participation can be carried out properly, it must prepare the staff members and the ability to know about the community, its history, tradition, beliefs, socioeconomic life, the form of government communication units in the community, leadership and awareness of the organization of the community ${ }^{10}$.

There are two approaches in the development of an institution, namely the topdown strategy (top-down strategy) and the bottom-up approach (bottom-up strategy). In the context of participation, it is more appropriate to apply the bottom-up approach (from the bottom up). This approach is based on the strength that comes from below, namely the community as a component of development. In this case, the community is required to actively contribute their role in the process of developing education in schools. in

9 Soetomo, Strategi-Strategi Pembangunan Masyarakat (Yogyakarta: Pustaka Pelajar, 2006), p. 84.

10 Nur Jihad, 'Manajemen Partisipasi Masyarakat dalam Program Pendidikan Islam' \{unpublished magister thesis, UIN Maliki Malang, Malang, 2010\}, p. 34. 
the context of the implementation of community participation, education is defined as the participation of community members (parents, general public and special communities) in assisting and cooperating for the success of school programs as an effort to improve quality in order to meet the needs of the community itself. The community is a group of people who are interrelated by the system, customs, and applicable law ${ }^{11}$.

According to Larry W. Canter, as quoted by Slamet Luwihono, community participation as feed-forward information (communication from the government to the public about a policy) and feedback information (communication from the public to the government over the policy). From the terminology standpoint, community participation can be interpreted as a way of interacting between two groups, namely groups that have not been included in the decision making the process (non-elite) and groups that have been making decisions (elit) ${ }^{12}$. Based on this understanding with the participation of the community in public policymaking, the interests of the community are taken into account in the process of public policymaking

Meanwhile, in the context of development, Stiefel and Wolfe, as cited by Suhirman, participation interprets as an organized effort to increase oversight of resources and regulatory institutions in certain social conditions by various groups and movements which until now have been sidelined in the oversight function. In this sense, participation is placed outside the state or formal government institutions. Participation is placed as community involvement, especially those seen as development beneficiaries, in consultation or

\footnotetext{
${ }^{11}$ Zulfi Mubarok, Sosiologi Agama Tafsir Sosial Fenomena Multi Religius Kontemporer (Malang: UIN Press, 2006), p. 5.

12 Slamet Luwihono, Perencanaan dan Pengannggaran Partisipatif untuk Good Governance (Bandung: FPPM, 2006), p. viii.
}

decision making at all stages of the development project cycle ${ }^{13}$.

In general, the definition of community participation in development is the participation of all members or representatives of the community to participate in making decisions in the process of development planning and management, including deciding the plans for activities to be implemented, benefits to be obtained, and how to implement and evaluate results of its implementation.

\section{The Islamic Narration on the Environment Issues}

In the perspective of Islam, humans and the environment have a very close relationship, because Allah created the universe, including humans and the environment in balance and harmony. This balance and harmony must be maintained to avoid the damage. The living sustainability in nature is also interrelated which if one component experiences an extraordinary disturbance, it will affect the other components. In the perspective of environmental ethics (ethics of environment), the most important component of the relationship between humans and the environment is human companionship. The purpose of religion is to protect, preserve and care for religion, life, intellect and reason, children and grandchildren. In addition, religion aims to care for equality and freedom. Protecting and caring for the environment is the main purpose of the relationship. If the environmental situation continues to deteriorate, the end life will no longer exist, of course, religion will no longer exist ${ }^{14}$.

Human is a dominant factor in environmental changes both good and bad and everything that happens in the environment and nature. In the Al-Quran, it is explained

\footnotetext{
${ }^{13}$ Suhirman, Kerangka Hukum dan Kebijakan Partisipasi Warga di Indonesia (Bandung: FPPM, 2006), p. 6.

14 Rabiah Harahap, 'Etika Islam dalam Mengelola Lingkungan Hidup', EduTech: Jurnal Ilmu Pendidikan Dan Ilmu Sosial, 1.01 (2015), 21-34.
} 
that a human cause the environmental damage both on land and at sea because the exploitation done by humans does not only meet the need to maintain life and does not consider environmental sustainability and natural balance. They wish to improve more the economic factors, power and fulfilment of endless lust ${ }^{15}$. The very central position and role of religion can be utilized to encourage the creation of an environment free from human destruction and greed.

Islam, with the spirit of "rabmatan li al'alamin (grace for the universe), must be realized as a force capable of encouraging humans to form attitudes and behaviours that care about the environment ${ }^{16}$, although the problem of environmental preservation and its prohibition on destruction has been presented in the messages of the Qur'an. In Abrar, environmental terms in al-Qur'an are mentioned in various forms, such as al-'alamin (species), al-sama '(space-time), al-ard (earth) and al-bi'ah (environment). The variants mentioned in the Qur'an principally illustrates the spirit of "rahmatan li al-'alamin", where the environment is not only affiliated on earth but includes all of nature, such as planet earth, space, and outer space. This concept indeed refers to the importance of maintaining the balance of ecosystems on earth and at the same time also having a relationship with ecosystems that exist outside the earth. The duty of preservation of the environment is not only for the earth but also other planetary environments ${ }^{17}$.

The Islamic values of environmental management when viewed from their source can be classified into two types, namely: 1) Divine value; divine Value is a value derived from the Qur'an and hadith. Divine value in

15 Harahap.

16 Arthur Saniotis, 'Muslims and Ecology: Fostering Islamic Environmental Ethics', Contemporar Islam, $\quad 6.2 \quad$ (2012), 155-71 <https://doi.org/10.1007/s11562-011-0173-8>.

17 Abrar, 'Islam dan Lingkungan', Jurnal Abkam, 12.3 (2009), 12-15. aspects of theology (the principle of faith) will never experience change and does not tend to change or follow human appetite. While the natural aspects can change according to the age and environment. 2) Human value; human value is the value that grows and develops based on human agreement. This spiritual value will continue to develop in a more advanced and higher direction. This value comes from ra'yu, customs and natural realities ${ }^{18}$. We need to know, the source of values that are not derived from the Qur'an and the Hadith can be used as long as they do not deviate or can support the value system that is based on the Qur'an and the Hadith. Meanwhile, according to Najma, environmental values when viewed from their orientation are categorized into four values, namely: 1) Ethical values; ethical value is a value that underlies their orientation on good and bad measures. 2) Pragmatic value; Pragmatic value is a value that underlies their orientation on success or failure. 3) Value of sensory effect: value of sensory effect is the value that underlies its orientation on something that is pleasant or sad. 4) Religious value: religious value is the value that underlies its orientation to sin and merit, halal and haram ${ }^{19}$.

In fact, according to Riyadi as quoted by Efendy, he states that Islam does not only regulate human relations with God (habl min Allah) but also regulates human relations with humans (babl min al-nâs) which covers all aspects of human life, such as social, cultural, political, legal, economics, state administration, environment, health, science and technology. Conceptually and philosophically, Islam has actually guided and managed humanity on the

${ }^{18}$ Ulin Niam Masruri, 'Pelestarian Lingkungan dalam Perspektif Sunnah', At-Taqaddum, 6.2 (2014), $411<$ http://journal.walisongo.ac.id/index.php/attaqad dum/issue/view/Volume November 2014>.

${ }^{19}$ Najma Mohamed, 'Islamic Education, EcoEthics and Community', Studies in Philosophy and Education, $\quad 33.3 \quad$ (2014), 315-28 <https://doi.org/10.1007/s11217-013-9387-y>. 
path to prosperity and happiness physically and spiritually, the world and the hereafter, and to accommodate all the positive values that exist in all aspects of life that humans need, including health, safety, and security ${ }^{20}$.

\section{Waste and Its Management}

The waste problem as one of the environmental problems can be said as a social problem that needs to be regulated because it affects the lives of the wider community as it is said that the environment is a supporting factor of human life.

One effort to solve the waste problem is to carry out waste management that can be done with the $3 \mathrm{R}$ principle (reduce, reuse, and recycle). $3 \mathrm{R}$ is the main principle of managing waste from its source, through various steps that are able to reduce the amount of waste that is discharged to the landfill ${ }^{21}$. The key to the success of the cleanliness and waste management program lies in the selection. Without the selection of waste treatment, it becomes difficult, expensive and at high risk of polluting the environment, and endangering health. The election is to separate types of waste from one type to another. The minimum selections are into two types:

a. Organic waste, which is non-recyclable waste that can be turned into valuable compost such as vegetables, fruits, and so on.

b. Non-organic waste, which is waste that can be recycled into other objects/items that can be useful again such as plastic, glass, metal, and so on ${ }^{22}$

The waste must be managed properly to the smallest extent so as not to disturb and threaten public health. Good waste management is not only for health purposes but also for the beauty of the environment. Waste management includes collection,

20 Ismail Efendy, 'Konstruksi Pendidikan Kesehatan Lingkungan dalam Perspektif Islam, MIQOT: Jurnal Ilmu-Ilmu Keislaman, 40.2 (2016) <https://doi.org/10.30821/miqot.v40i2.305>.

${ }^{21}$ Hernawati, Saleh, and Suwondo.

${ }^{22}$ Sulistiyorini, Darwis, and Gutama. transportation, destruction or management of waste in such a way that waste does not disturb public health and the environment. Ways of managing waste in Nabila can be done include; (1) Garbage collection and transportation. Garbage collection is the responsibility of each household or industry that produces waste. Therefore, they must build or hold a special place and then from each of the waste collection sites must be transported to the garbage collection place (TPS) and then to the final shelter (TPA). The mechanism of the system or method of transportation for urban areas is the responsibility of the local government which is supported by community participation in waste production, especially in terms of funding. Whereas for rural areas in general, it can be managed by each family, without the need for TPS or TPA. Rural household waste is generally recycled into fertilizer; (2) Destruction and waste management. Destruction and management of solid waste can be done in various ways, including: planted (landfill), burned (incineration, made into fertilizer (composting), animal feed (hog feeding). Reuse (recycling) ${ }^{23}$.

Good and proper waste management can not only leave cleanliness and environmental aesthetics, but it can also eliminate or inhibit the proliferation of vectors of various infectious diseases that can harm public health.

\section{General Policy on Environmental Management}

The population of Bukittinggi has increased since the end of 2016 to 101,276 people, consisting of 50,024 men and 51,252 women with a composition of 30,562 children and the remaining 70,714 adults, with an average growth rate of $2.69 \%$ per -year. Population density has not been evenly distributed and is generally concentrated in

\footnotetext{
${ }^{23}$ Sofia Nabila, Ari Handono Ramelan, and Dwi Aries Himawanto, 'Model Pemberdayaan Masyarakat dalam Kumuh di Kelurahan Mojosongo', Seminar Nasional Kimia dan Pendidikan Kimia VIII, 2016, 188-97.
} 
Guguk Panjang District with the highest population density of 5,606 people $/ \mathrm{km}^{24}$.

Based on data from the Bukittinggi City Sanitation and Landscaping Office in 2012, the amount of garbage generated by Bukittinggi City was 252,945 m3 / day and the garbage collected was $168.64 \mathrm{~m} 3$ / day. The percentage of garbage collected is $66.67 \%$. The quality standard of garbage collected according to Permen PU No. 14 of 2010 concerning Minimum Service Standards for Public Works and Spatial Planning. The standard for the amount of waste collected is $70 \%$. The quality standard for urban solid waste is obtained from the calculation of urban solid waste according to SNI 19 3964-1994 with the provisions of municipal solid waste. Bukittinggi city with a population of 114,415 people, including the city is medium. Garbage collection for medium cities is 21 / person / day ${ }^{25}$.

Waste handling conditions in Bukittinggi City initially began with the collection and sweeping, transportation and disposal at the Final Processing Site (TPA). The collection process is carried out by involving community participation in which the community conducts the waste from each of their houses, then collects the waste to the Secondary Temporary Collection Site (TPS). Furthermore, from the TPS, the garbage is transported by a garbage truck from the Bukittinggi City Sanitation and Parks Agency to be disposed of at the TPA ${ }^{26}$.

In tourist attractions, the garbage is put in the garbage, then collected in a TPS or container, then transported to the final processing site. In the hospital waste management, there are some hospitals that

\footnotetext{
${ }^{24}$ BPS Kota Bukittinggi, Bukittinggi dalam Angka (Bukittinggi: Grafiti, 2000), p.143.

${ }^{25}$ Yenni Ruslinda, Shinta Indah, and Widya Laylani, 'Studi Timbulan, Komposisi dan Karakteristik Sampah Domestik Kota Bukittinggi', Jurnal Teknik Lingkungan, 9.1 (2012), 1-12 <https://doi.org/10.1007/3-540-36271-1_12>.

${ }^{26}$ Risman (Head of sanitation department of Bukittinggi), Interview \{Wednesday, 18 July 2018\}.
}

have handled themselves, especially large hospitals that already have generators. Waste that is managed specifically for B3 waste (for example syringes, sanitary napkins), while the non-hazardous waste is carried out by the Bukittinggi City Sanitation Department and finally disposed of in the TPA.

Garbage transportation is carried out 3 (three) times a day by operating 16 trucks. During the day, there are eight tracks, while in the afternoon and the night around three to four trucks. Existing is located in the village of Puhun Pintu Kabun with an open system that is direct disposal into Ngarai Sianok ${ }^{27}$.

The following is the solid waste service system chart 1 in Bukittinggi City:

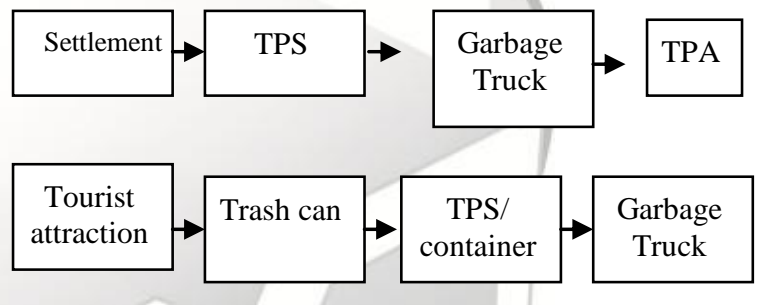

Chart 1. Waste Service System

In addition, the implementation of the National Community-Based Water Supply and Environmental Sanitation (AMPL-BM) program in West Sumatra Province has been started since 2004 in Solok Regency, Sawahlunto Sijunjung Regency, Tanah Datar District, Payakumbuh City, Bukittinggi City and Pesisir Selatan Regency.

\section{The Real Condition of Community Participation in Waste Management in Bukittinggi City}

Community-based waste management needs to be improved by increasing the number of environmentally conscious community groups that can manage organic waste, especially in densely populated villages. The formation of this group can be done through cooperation with the agriculture

\footnotetext{
${ }^{27}$ Niko (Staf of sanitation department of Bukittinggi), Interview \{Friday, 20 July 2018\}.
} 
department in the development of processing organic waste into compost, pesticides, concrete blocks, biogas, and so on. Inorganic waste also needs to be managed by community institutions, such as, making garbage banks and sold to factories that can process the waste into new products.

Based on an interview with the head of sanitation department of Bukittinggi City, $\mathrm{He}$ stated that public awareness in Bukittinggi City is still minimal in environmental management as many people do not separate organic, inorganic, and B3 waste. The waste should be sorted in the household to facilitate waste processing. The waste containers should encourage recycling efforts, which are adjusted to the type of waste that has been disaggregated. The guidance that is carried out should separate organic, inorganic, and hazardous waste. It then continues until processing ${ }^{28}$. Non-separated waste types also cause the absence of waste management. To generate public interest in wanting to separate waste according to its type, it can be started by providing a communal container consisting of three types, namely green for organic waste, yellow for inorganic waste, and red for B3. Furthermore, the government invited the PKK as the organization closest to the community, especially housewives, to invite them to separate waste from the household.

Thus, participation and public awareness of Bukittinggi in environmental management is considered to be lacking. The community still depends on the role of the government through the cleaning service in managing environmental cleanliness such as waste. This is consistent with Rubbyatna's research showing that the factors that influence the low level of community participation include population density and traffic, community rejection, proximity to rivers and flood-free as

28 Risman (Head of sanitation department of Bukittinggi), Interview \{Wednesday, 18 July 2018\}. well as community regulation and socio-culture in urban types such as Bukittinggi ${ }^{29}$.

\section{Public Narration and the Role of Religion Leaders in Campaigns about Waste}

Islam as a foundation for environmental management, is easily and popularly portrayed by religious leaders through their religious lectures. Even some propositions in Islam can be related to the background of the sciences possessed by religious leaders and preachers, it should also influence the awareness of Muslim communities towards their environment. According to Widodo, the religious leaders and preachers who truly understand, they think that the Islamic religion guides and directs its adherents to be kind in a comprehensive manner including the environment, because it is regulated in Islamic arguments $^{30}$.

In addition, the transformation of Da'i approach with an environmental perspective into people's lives on the basis of religious spirituality is through the lectures and Friday sermons. These activities are based on an ethical basis for forest conservation and saving. This approach has been responded positively by the community and this activity has become the spearhead of nature and the environmental conservation movement ${ }^{31}$.

Meanwhile, the narration and opinion that developed in the Muslim community of Bukittinggi, one of them, Syamsuddin, also realized that the community had a view that

${ }^{29}$ Rubbyatna, A., 'Kajian Faktor-Faktor yang Mempengaruhi Penentuan Lokasi Transfer Depo Sampah (TDS) di Kota Slawi Kabupaten Tegal' \{unpublished magister thesis, Universitas Diponegoro, Semarang, 2009\}, p. 21.

${ }^{30}$ Widodo Brontowiyono, Asep Supriyadi, and Rendy Bayu Aditya, 'Persepsi dan Peran Tokoh Agama Islam di Kabupaten Sleman dalam Upaya Pengelolaan Lingkungan Hidup', Jurnal Lingkungan Hidup, 6 (2014), 63-70.

${ }^{31}$ Jumarddin La Fua and Ismail Suardi Wekke, 'Islam dan Konservasi: Pendekatan Dakwah dalam Pelestarian Lingkungan', Al-Tabrir: Jurnal Pemikiran Islam, $\quad 17.2 \quad$ (2017), 411 <https://doi.org/10.21154/altahrir.v17i2.998>. 
religion had a message to protect the environment ${ }^{32}$. In another perspective, Badri said that "the almighty created the universe for his people. I only do what the Almighty commands" ${ }^{33}$. Bukittinggi Muslim society generally realizes that the universe including the whole world is an empirical reality that does not stand alone, but it is related to other realities that are non-empirical and transcendent. Everything in the universe is a sign of the existence of the unseen. This means that Bukittinggi Muslim community realizes that environmental activities are integrated and inseparable from their monotheism.

However, the awareness about the importance of protecting the environment is not in line with the awareness of doing and participating in maintaining the integrity of their environment. It is not immediately known that the low level of community participation is influenced by religious awareness, because low participation is also influenced by other factors such as social and other policies.

The analysis in the religious dimension, especially, found that the awareness of environmental awareness has not been institutionalized in the collective social action of Muslims. This dimension is still in the realm of awareness in the belief even the highest personal awareness of Muslims who only practice environmental awareness personally and individually. In this context, what they are doing is beyond the particular theological object by Amin Abdullah, as quoted by Ridwan, that their environmental awareness is still in a more transcendental-spiritual area. ${ }^{34}$ The unconditional surrender to the Creator, a

\footnotetext{
${ }^{32}$ Syamsuddin (Muslim community), Interview (Monday, 14 Augustus 2018).

${ }^{33}$ Badri (Ulama), Interview (Monday, 14 Augustus 2018).

34 Benny Ridwan, 'Kesadaran dan Tanggungjawab Pelestarian Lingkungan Masyarakat Muslim Rawa Pening Kabupaten Semarang', Inferensi,
}

call to do good for fellow-creatures, recognition of the existence of the "holy", a sense of dependence on the "almighty" everything, requests and prayers for guidance on safe paths and so on are among the areas mentioned as a region that is transcendental. However, this awareness has not yet been reflected in their attitudes and behaviour in terms of environmental awareness and participation.

However, knowledge of ethics (the environment) continues to be promoted by related agencies, such as the education office, the health service, the sanitation and environmental service, the social service and others. The condition of the future community will have knowledge about the environment and ethics (environment) which in the end these traits will be attached to individuals so that they become a part of their lives and they love their environment and take an active part in preserving the environment in which they are located ${ }^{35}$.

\section{The Role of Islamic Philanthropy} Workshop on Establishing a Waste Bank

Currently, the Philanthropy Program is very popular in the form of Corporate Social Responsibilities pioneered by financial institutions in collaboration with religious institutions such as Baznas and others who have channelled funds for charity and productive humanitarian programs. Philanthropy is also one of the elements in religious teachings that pay attention to the benefit for society, especially the poverty and protecting the environment ${ }^{36}$.

7.2

(2013), 321

<https://doi.org/10.18326/infsl3.v7i2.321-342>

35 Eko Ariwidodo, 'Relevansi Pengetahuan Masyarakat Tentang Lingkungan dan Etika Lingkungan dengan Partisipasinya dalam Pelestarian Lingkungan', Ilmu Sosial dan Keagamaan Islam, 11.1 (2014), 1-20.

${ }^{36}$ Imron Hadi Tamin, 'Peran Filantropi dalam Pengentasan Kemiskinan di dalam Komunitas Lokal', Jurnal Sosiologi Islam, 1.1 (2011), 35-58 $<$ http://jsi.uinsby.ac.id/index.php/jsi/article/view/4>. 
Bukittnggi City Baznas on April 13, 2017, held a Waste Bank Formation Workshop at the Bukittinggi City BAZNAZ Building. This event aims to initiate and prepare 5 (five) RW groups in the ATTS village which will form 5 (five) new waste bank units in 2017. The workshop was attended by +90 participants who would become the management and members of the waste bank that would be formed and the Bukittinggi DLH and Bukittinggi waste bank association delegates.

In this workshop, the acclamation of five (5) waste bank units was formed in the ATTS village, namely Rose waste Bank, Dahlia waste Bank, Cambodian Waste Bank, Anggrek Waste Bank and Serunai Waste Bank whose legality was formed through the ATTS village Decree. The Office of the Environment of West Sumatra Province this year will provide assistance to the 5 (five) waste bank units for the next +4 months starting from April to July 2017. The assistance services will be provided by the Facilitator (Ir. Syaifuddin Islami) to each group with a schedule determined according to the agreement ${ }^{37}$.

\section{The Model of Waste Bank Management in Bukittinggi}

To support the handling of waste that is relevant to the economic and ecological side, it is needed integrated waste management. Integrated waste management involves the involvement of the general public, special communities (solid waste entrepreneurs and scavengers), the private sector, and the government as facilitators. The general public is prioritized, namely the local community who are more aware of the waste problem in their area.

Thus, the problem of waste is not only the business of the Bukittinggi government and other agencies, because the completion of the handling of the waste requires the involvement of all relevant parties in the Bukittinggi. Waste

${ }^{37}$ Rahman (Head of Baznas), Interview (Friday, 11 Augustus 2018). is a consequence of the human activity. Every human activity will definitely produce waste or garbage. The increasing population of the Bukittinggi automatically causes a lot of garbage generated from the activities of the population that we use every day. Waste management in the Bukittinggi is currently not maximally managed.

Regional Regulation Number 14 of 2009 Bukittinggi explains that waste management is a shared responsibility between the Regional Government and the community. Community activities in carrying out waste management include maintaining cleanliness in their respective environments, both personally and in cooperation; sorting waste according to type, provision of trash bins in a closed manner with the amount according to needs. The above regulation is clear that to create a clean environment is not only the responsibility of the government but also the responsibility of the community ${ }^{38}$.

One of the programs in order to the community cares and participates in creating a clean environment is a waste bank. Waste bank is a place to collect various kinds of waste that have been separated according to the type to be deposited to the environmental workshop or more familiarly called the Waste bank, the results of waste deposits will be saved and can be taken or thawed within a certain time period by adopting banking principles, so the waste depositor will get a savings book. The waste Bank is an alternative to encourage citizens to care about waste and its problems.

Currently, the Bukittinggi government encourages citizen participation in the formation of a waste bank. Among the waste banks that have been formed, 16 are managed by the community based on Table 1 :

38 Mentari, Yurni Suastri, and Fitriana Syahar, 'Partisipasi Pedagang Kaki Lima dalam Pengelolaan Sampah di Pasar Bawah Kota Bukittinggi', Jurnal Buana, 2.5 (2018), 328-37. 
Table 1. The Waste Bank Data in the Bukittinggi

\begin{tabular}{|l|l|l|l|}
\hline No & $\begin{array}{l}\text { The Name of Waste } \\
\text { Bank }\end{array}$ & Kelurahan & $\begin{array}{l}\text { Condi } \\
\text { tion }\end{array}$ \\
\hline 1 & Waste Bank of My Darling & $\begin{array}{l}\text { Belakang } \\
\text { Balok }\end{array}$ & Active \\
\hline 2 & Waste Bank of Amanah & BCKR & Active \\
\hline 3 & $\begin{array}{l}\text { Waste Bank of Tarok Dipo } \\
\text { Berseri }\end{array}$ & Tarok Dipo & Active \\
\hline 4 & Waste Bank of Berkah & $\begin{array}{l}\text { Kelurahan } \\
\text { Birugo }\end{array}$ & Active \\
\hline 5 & Waste Bank of Fordecok & $\begin{array}{l}\text { Benteng } \\
\text { Pasar Atas }\end{array}$ & Active \\
\hline 6 & $\begin{array}{l}\text { Waste Bank of Sedap } \\
\text { Malam }\end{array}$ & $\begin{array}{l}\text { Pulai Anak } \\
\text { Air }\end{array}$ & Active \\
\hline 7 & $\begin{array}{l}\text { Waste Bank of Tanjung } \\
\text { Indah }\end{array}$ & Ipuh & Active \\
\hline 8 & $\begin{array}{l}\text { Waste Bank of Mutiara } \\
\text { Indah }\end{array}$ & $\begin{array}{l}\text { Aua } \\
\text { Tajungkang }\end{array}$ & Active \\
\hline 9 & $\begin{array}{l}\text { Waste Bank of Saayun } \\
\text { Salangkah }\end{array}$ & $\begin{array}{l}\text { Puhun } \\
\text { Pintu } \\
\text { Kabun }\end{array}$ & Active \\
\hline 10 & Waste Bank of Koto Selayan & $\begin{array}{l}\text { Koto } \\
\text { Selayan }\end{array}$ & $\begin{array}{l}\text { Non } \\
\text { Active }\end{array}$ \\
\hline 11 & Waste Bank of Pakan Kurai & $\begin{array}{l}\text { Pakan } \\
\text { Kurai }\end{array}$ & $\begin{array}{l}\text { Non } \\
\text { Active }\end{array}$ \\
\hline 12 & Waste Bank of Aur Kuning & $\begin{array}{l}\text { Aur } \\
\text { Kuning }\end{array}$ & $\begin{array}{l}\text { Non } \\
\text { Active }\end{array}$ \\
\hline 13 & $\begin{array}{l}\text { Waste Bank of Ladang } \\
\text { Cakiah }\end{array}$ & $\begin{array}{l}\text { Ladang } \\
\text { Cakiah }\end{array}$ & $\begin{array}{l}\text { Non } \\
\text { Active }\end{array}$ \\
\hline 14 & Waste Bank of Parit Antang & $\begin{array}{l}\text { Parit } \\
\text { Antang }\end{array}$ & $\begin{array}{l}\text { Non } \\
\text { Active }\end{array}$ \\
\hline Tandah Bank of Birugo & Birugo & $\begin{array}{l}\text { Non } \\
\text { Active }\end{array}$ \\
\hline
\end{tabular}

Source: The data on the department of environment and parks 2017

As for the work system in this waste bank, the rubbish deposited in the waste bank is distinguished by several types, such as organic waste such as chunks of vegetables, remaining organic and non-organic dishes such as plastic, iron and others. That way waste that can still be recycled, such as organic materials, can be used for compost or biogas. While non-organic materials are recycled into various furniture such as bags, sandals and others. The waste bank in its implementation can reduce the high rate of waste in the community and at the final disposal site (TPA) so that the volume of waste in the community and TPA can be reduced. Waste bank management also follows the rules contained in Act number 18 of 2008 concerning waste management, that the principle in managing waste is reduce, reuse and recycle $(3 \mathrm{R})^{39}$.

Waste bank is a place to collect various kinds of waste that have been separated according to the type to be deposited to the environmental workshop or more familiarly called the Waste bank, the results of waste deposits will be saved and can be taken or thawed within a certain time period by adopting banking principles, so the waste depositor will get a savings book.

Waste bank is one of the strategies to build community awareness so that they can care about waste to get direct economic benefits from waste. So, a waste bank cannot stand alone but must be integrated so that the immediate benefits are felt not only by the economy but the development of a clean, green and healthy environment. Waste banks can also be used as a solution to achieve clean and comfortable settlements for its citizens. With this pattern, citizens in addition to being disciplined in managing waste.

Waste bank management is not only policy-oriented and business-oriented work but requires community-based management. Based on interviews and observations by the author, there are several important aspects of waste management including waste bank management, namely reorientation, social movements, social institutions, and capacity development.

The waste bank is a concept of collecting dry and sorted waste and has management like a bank but what is saved is not money but waste. Savers who are also called customers have a savings book and can borrow money that will later be returned with waste worth and the money borrowed. Waste that is saved is weighed and valued with a certain amount of

${ }^{39}$ Devi Hernawati, Choirul Saleh, and Suwondo, 'Partisipasi Masyarakat dalam Pengelolaan Sampah Berbasis 3R (Reduce, Reuse dan Recycle) (Studi pada Tempat Pengelolaan Sampah Terpadu di Desa Mulyoagung Kecamatan Dau Kabupaten Malang), Jurnal Administrasi Publik, 1.2 (2005), 181-87. 
money that will later be sold at the factory that is already cooperating. Whereas plastic packaging is bought by local PKK women to be recycled into handicraft items. Waste management with the concept of the Waste Bank is a strategy in building public awareness so that they can be friends with waste to get direct economic benefits from waste. Waste banks can also be used as a solution to achieve clean and comfortable settlements for its citizens. With this pattern, in addition to being disciplined in managing waste, the community also receives additional income from the garbage they collect.

Waste management with a waste bank system is expected to be able to help the government in handling waste and increasing the community's economy. The phenomenon that occurs is; (1) There are still people who do not care about their environment. This can be seen from the fact that there are still some housing residents whose rubbish is not managed properly so that it is scattered and makes the environment unhealthy; (2) The Muslim community of Bukittinggi has not yet fully contributed to the continuity of the waste bank. This is based on the lack of public knowledge of the waste bank; (3) The assistance provided by the government is inadequate, this can be seen in the waste bank in various places of Bukittinggi, the management still complains about the limited facilities and infrastructure in running the waste bank.

\section{Conclusion}

The narrative, opinion and public awareness about the environment apparently did not affect the high participation of Muslim communities in environmental management, especially waste management in Bukittinggi. The diversity of responses and the community's response influenced the involvement and even awareness in managing their environment.
In addition, community-based management policies are not only policyoriented and business-oriented work but require community-based management and management. Based on interviews and observations by the author, there are several important aspects of waste management and management including waste bank management, namely reorientation, social movements, social institutions, and capacity development.

The environmental management system, especially community-based waste of Bukittinggi in general has not been running well as evidenced by the non-implementation of environmental regulations and policies plus the absence of special planning in management of community-based waste management due to several obstacles including the lack of public awareness, the absence of waste management sites and limited processing costs.

However, the implementation of waste management in several communities in the Bukittinggi has been proven by the fact that there are centres of waste management by making compost, recycling and waste banks. However, assistance from relevant parties and NGOs and universities is needed to manage waste management in Bukittinggi. In terms of public policy, a special regional regulation on waste is needed, the development of methods of waste management and socialization to the community to carry out $3 \mathrm{R}$ so that it can improve people's behaviour in disposing of waste so that the amount of waste produced does not endanger the health and the environment.

\section{References}

\section{Books}

Iskandar, Johan, Ekologi Manusia dan Pembangunan Berkelanjutan (Bandung: Program Studi Magister Ilmu Lingkungan Universitas Padjajaran, 2009) 
Luwihono, Slamet, Perencanaan dan Pengannggaran Partisipatif Untuk Good Governance (Bandung: FPPM, 2006)

Moeliono, A.M., Kamus Besar Bahasa Indonesia (Jakarta: Balai Pustaka, 1990)

Mubarok, Zulfi, Sosiologi Agama Tafsir Sosial Fenomena Multi Religius Kontemporer (Malang: UIN Press, 2006)

Sarwono, Sarlito Wirawan, Psikologi Lingkungan (Jakarta: PT Gramedia, 1992)

Soetomo, Strategi-Strategi Pembangunan Masyarakat (Yogyakarta: Pustaka Pelajar, 2006)

Suhirman, Kerangka Hukum dan Kebijakan Partisipasi Warga di Indonesia (Bandung: FPPM, 2006)

Tim BPS Kota Bukittinggi, Bukittinggi dalam Angka (Bukittinggi: Grafiti, 2000)

\section{Journals}

Abrar, 'Islam dan Lingkungan', Jurnal Abkam, 12 (2009), 12-15

Ariwidodo, Eko, 'Relevansi Pengetahuan Masyarakat tentang Lingkungan dan Etika Lingkungan dengan Partisipasinya dalam Pelestarian Lingkungan', Ilmu Sosial dan Keagamaan Islam, 11 (2014), 1-20

Brontowiyono, Widodo, Asep Supriyadi, and Rendy Bayu Aditya, 'Persepsi dan Peran Tokoh Agama Islam di Kabupaten Sleman dalam Upaya Pengelolaan Lingkungan Hidup', Jurnal Lingkungan Hidup, 6 (2014), 63-70

Efendy, Ismail, 'Konstruksi Pendidikan Kesehatan Lingkungan dalam Perspektif Islam', Miqot: Jurnal Ilmu-Ilmu Keislaman, 40

$<$ Https://Doi.Org/10.30821/Miqot.V40 i2.305>

Fua, Jumarddin La, and Ismail Suardi Wekke, 'Islam dan Konservasi: Pendekatan Dakwah dalam Pelestarian Lingkungan', Al-Tahrir: Jurnal Pemikiran Islam, 17 (2017), 411 $<$ Https://Doi.Org/10.21154/Altahrir.V 17i2.998>

Harahap, Rabiah, 'Etika Islam dalam
Mengelola Lingkungan Hidup', Edutech: Jurnal Ilmu Pendidikan dan Ilmu Sosial, 1 (2015), 21

Hernawati, Devi, Choirul Saleh, and Suwondo, 'Partisipasi Masyarakat dalam Pengelolaan Sampah Berbasis 3R (Reduce, Reuse dan Recycle) (Studi pada Tempat Pengelolaan Sampah Terpadu di Desa Mulyoagung Kecamatan Dau Kabupaten Malang)', Jurnal Administrasi Publik (Jap), 1 (2019), 181-87 $<$ Https://Doi.Org/10.1017/Cbo978110 7415324.004>

Imron Hadi Tamin, 'Peran Filantropi dalam Pengentasan Kemiskinan di dalam Komunitas Lokal', Jurnal Sosiologi Islam, 1 (2011), 35-58 $<$ Http://Jsi.Uinsby.Ac.Id/Index.Php/Jsi /Article/View/4>

Masruri, Ulin Niam, 'Pelestarian Lingkungan dalam Perspektif Sunnah', At-Taqaddum, 6 (2014), $411-28$ $<$ Http://Journal.Walisongo.Ac.Id/Index .Php/Attaqaddum/Issue/View/Volume $6 \% 2$ c Nomor 2\%2c November 2014>

Mentari, Yurni Suastri, and Fitriana Syahar, 'Partisipasi Pedagang Kaki Lima dalam Pengelolaan Sampah di Pasar Bawah Kota Bukit 'Tinggi', Jurnal Buana, 2 (2018), 328-37

Mohamed, Najma, 'Islamic Education, EcoEthics and Community', Studies In Philosopby And Education, 33 (2014), 31528 <Https://Doi.Org/10.1007/S11217013-9387-Y>

Nabila, Sofia, Ari Handono Ramelan, and Dwi Aries Himawanto, 'Model Pemberdayaan Masyarakat dalam Kumuh di Kelurahan Mojosongo', Seminar Nasional Kimia Dan Pendidikan Kimia Viii, 2016, 188-97

Nilam Sari, Putri, 'Analisis Pengelolaan Sampah Padat di Kecamatan Banuhampu Kabupaten Agam', Jurnal Kesehatan Masyarakat Andalas, 10 (2017), 157 $<$ Https://Doi.Org/10.24893/Jkma.V10i $2.201>$

Ridwan, Benny, 'Kesadaran dan Tanggungjawab Pelestarian Lingkungan Masyarakat Muslim Rawa Pening 
Kabupaten Semarang', Inferensi, 7 (2013), 321

$<$ Https://Doi.Org/10.18326/Infsl3.V7i $2.321-342>$

Ruslinda, Yenni, Shinta Indah, and Widya Laylani, 'Studi Timbulan, Komposisi dan Karakteristik Sampah Domestik Kota Bukittinggi', Jurnal Teknik Lingkungan, 9 (2012), $1-12$ $<$ Https://Doi.Org/10.1007/3-54036271-1_12>

Saniotis, Arthur, 'Muslims and Ecology: Fostering Islamic Environmental Ethics', Contemporary Islam, 6 (2012), 155-71 $<$ Https://Doi.Org/10.1007/S11562011-0173-8>

Saribanon, N, E Soetarto, S Hadi Sutjahjo, 'Pengelolaan Sumberdaya dan Pendekatan Tipologi dalam Pengembangan Partisipasi Masyarakat', Jurnal Pengabdian Masyarakat, 8 (2007), 235-44

Sulistiyorini, Nur Rahmawati Sulistiyori, Rudi Saprudin Darwis, and Arie Surya Gutama, 'Partisipasi Masyarakat dalam Pengelolaan Sampah di Lingkungan Margaluyu Kelurahan Cicurug', Prosiding Penelitian dan Pengabdian Kepada Masyarakat, 3 (2016), 414 <Https://Doi.Org/10.24198/Jppm.V3i3 $.13786>$

\section{Other references}

Jihad, Nur, 'Manajemen Partisipasi Masyarakat dalam Program Pendidikan Islam' \{unpublished magister thesis, UIN Maliki Malang, Malang, 2010\}

Manvi, Sri Dzarrah Hayati, 'Efektifitas Pelaksanaan Pembuangan Sampah Kota Bukittinggi ke Tempat Pemrosesan Akhir (TPA) Regional Kota Payakumbuh Menurut Undang-Undang No 18 Tahun 2008 Tentang Pengelolaan Sampah', \{unpublished bachelor thesis, UMSB Sumatera Barat, Padang, 2004\}

Rubbyatna, A., 'Kajian Faktor-Faktor yang Mempengaruhi Penentuan Lokasi Transfer Depo Sampah (TDS) di Kota Slawi Kabupaten Tegal' \{unpublished magister thesis, Universitas Diponegoro, Semarang, 2009\}

\section{Interviews}

Badri (Ulama), Interview (Monday, 14 Augustus 2018)

Niko (Staf of sanitation department of Bukittinggi), Interview \{Friday, 20 July $2018\}$

Rahman (Head of Baznas), Interview (Friday, 11 Augustus 2018)

Risman (Head of sanitation department of Bukittinggi), Interview \{Wednesday, 18 July 2018\}

Syamsuddin (Muslim community), Interview (Monday, 14 Augustus 2018) 